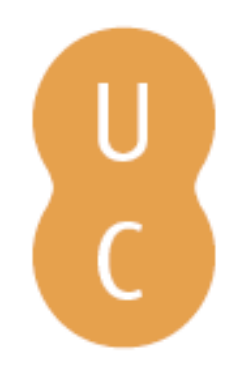

\title{
nombalina
}

\section{Qual o legado principal de Paul Ricoeur à Filosofia Contemporânea?}

\author{
Autor(es): Japiassu, Hilton
}

Publicado por: Imprensa da Universidade de Coimbra

URL

persistente: URI:http://hdl.handle.net/10316.2/43637

DOI: $\quad$ DOl:https://doi.org/10.14195/978-989-26-1516-5_7

Accessed : $\quad$ 26-Apr-2023 10:37:31

A navegação consulta e descarregamento dos títulos inseridos nas Bibliotecas Digitais UC Digitalis, UC Pombalina e UC Impactum, pressupõem a aceitação plena e sem reservas dos Termos e Condições de Uso destas Bibliotecas Digitais, disponíveis em https://digitalis.uc.pt/pt-pt/termos.

Conforme exposto nos referidos Termos e Condições de Uso, o descarregamento de títulos de acesso restrito requer uma licença válida de autorização devendo o utilizador aceder ao(s) documento(s) a partir de um endereço de IP da instituição detentora da supramencionada licença.

Ao utilizador é apenas permitido o descarregamento para uso pessoal, pelo que o emprego do(s) título(s) descarregado(s) para outro fim, designadamente comercial, carece de autorização do respetivo autor ou editor da obra.

Na medida em que todas as obras da UC Digitalis se encontram protegidas pelo Código do Direito de Autor e Direitos Conexos e demais legislação aplicável, toda a cópia, parcial ou total, deste documento, nos casos em que é legalmente admitida, deverá conter ou fazer-se acompanhar por este aviso.

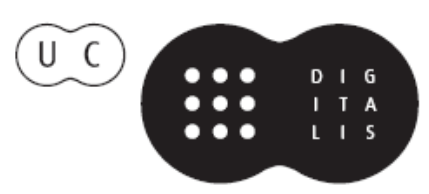


善商

Gonçalo Marcelo

César Correa Arias

Patrícia Lavelle

\#1

Tomás Domingo Moratalla COORDS.

A Atualidade

de Paul Ricour

numa Perspetiva

Ibero-Americana

Imprensa da Universidade de Coimbra

Coimbra University Press 
A Ricœuriana é uma série de livros (abrangendo monografias e volumes coletivos) disponibilizados em acesso aberto, dedicada à obra de Paul Ricœur e aberta a contribuições que também versem sobre outros autores e áreas, fomentando um permanente espírito de diálogo e interdisciplinaridade. As suas publicações abrangem diversos domínios da filosofia (estética, ética, fenomenologia, filosofia social e política, hermenêutica), mas também de disciplinas como os estudos literários, a história, a psicanálise, e a teologia, entre outras áreas relevantes para o pensamento de Ricœur. 


\title{
QUAL O LEGADO PRINCIPAL DE PAUL RICAUR
} À FILOSOFIA CONTEMPORÂNEA?

\author{
WHAT IS PAUL RICEER'S MAIN LEGACY \\ TO CONTEMPORARY PHILOSOPHY?
}

Hilton Japiassu ${ }^{1}$

O eixo fundamental desse filósofo que considero um dos mais fecundos, abertos e dialógicos de nosso tempo, reside em ter tomado como seu problema próprio o da extração e interpretação do sentido (Hermenêutica) permitindo-lhe elaborar uma simbólica da consciência que se encontra na raiz mesma de todas as determinações históricas e espirituais do homem contemporâneo. Ao partir de uma análise rigorosa da vontade humana, buscou atingir e formular uma teoria do ser utilizando a fenomenologia como seu momento metodológico decisivo, a fim de detectar e analisar os problemas reais colocados pelos homens atuais no interior da História. Ao utilizar o pensamento dos outros pensadores ou cientistas como instrumento para sua própria recriação de conceitos, sua ambição foi a de pensar a totalidade do bomem (cognoscente, sentinte e agente) sem jamais reduzi-lo a uma faculdade de conhecimento.

${ }^{1}$ Hilton Japiassu† era doutorado em Filosofia pela Université des Sciences Sociales de Grenoble e Professor aposentado da Universidade Federal do Rio de Janeiro (UFRJ). 
Convencido de que o símbolo nos leva a pensar (representa um conteúdo inconsciente), fez da Hermenêutica um trabalho e uma tarefa intelectuais de decodificar o sentido oculto por detrás do sentido manifesto, notadamente nos fenômenos concernentes à vida humana e a seu destino. Donde sua Filosofia se apresentar sempre como uma atividade ao mesmo tempo concreta, temporal e pessoal, mas com pretensões à universalidade e aberta à Transcendência, pois sua esperança é uma flâmula na noite. Como um dos últimos Mâ̂tre à penser, e a fim de responder aos grandes desafios de seu tempo, não hesitou em sair do corpus propriamente filosófico para deixar-se interpelar pelos problemas de um Lebenswelt (Mundo da Vida), mas com Leben e com Welt, pois jamais deixou de consagrar sua reflexão sobre os conhecimentos novos que modificam nossas concepções do mundo, do real e do homem.

Filósofo de todos os diálogos, abriu a interrogação filosófica a uma busca frenética pelo sentido ao refletir em profundidade sobre os problemas vividos pelos homens concretos na Cidade. Donde sua obra ser considerada sem fronteiras servindo-nos de uma incrível mina de inspiração e instigando-nos a encontrar uma Ética adaptada à nossa modernidade e a seus novos desafios, notadamente o de resgatar uma utopia em sua função libertadora capaz de impedir o horizonte de expectativas de confundir-se com o simples campo da experiência. Porque o luto das visões teológicas pode se transformar numa chance para podermos refundar um projeto de futuro comum a partir do reexame permanente dos possíveis não realizados em nosso passado. Donde seu empenho em revivificar, rejuvenescer e descobrir o sopro inicial do desejo de estar sempre voltado para a ação e o presente. Donde sua busca constante de recarregar de energia uma deontologia da vontade graças a uma "teleologia do desejo". Seu pensamento, podendo ser considerado uma lição de coragem contra todas as formas de despistes, sejam eles céticos, fatalistas ou niilistas, abre-nos os caminhos de uma 
esperança exigente, convocando-nos a jamais nos esquecermos da responsabilidade e da dignidade humanas, pois, como dizia a frase de Heidegger, a ser entendida como um apelo: "a origem não se encontra atrás de nós, mas em nossa frente”. Porque, não só o indivíduo, mas também a sociedade possui um projeto, um horizonte de expectativas e de esperança permitindo-nos fazer do sentido atribuído ao passado uma fonte potencial para a construção de nosso futuro no qual o homem precisa se conceber como ser-com, cuidando de sua alma e, para ser feliz, praticando (como ensinara Sócrates) tudo o que é bom, honesto e justo, sem se esquecer do que já dizia Heráclito (séc. VI a.C.): "a mais bela harmonia nasce das diferenças".

Testemunho recolhido por Claudio Reichert do Nascimento Universidade Federal do Oeste da Bahia - Campus Barreiras 